\title{
Military forensic psychiatry
}

\author{
MARK A. TURNER and LEIGH A. NEAL
}

Traumatic psychological and functional somatic syndromes in military personnel, following recent conflicts, have generated considerable interest in recent years (Jones et al, 2002). However, there has been near-total academic neglect of forensic military psychiatry, despite the anticipated major changes in British military psychiatric provision (Winyard, 2001) and the military judicial system (Syal, 2002). The indications are that civilian psychiatrists are likely to become increasingly involved in all aspects of the assessment and treatment of mental illnesses in service personnel. This demands a knowledge of the British military judicial system, and the relationship between mental illness and criminality in the military, extending beyond that usually required of a civilian psychiatrist.

\section{THE MILITARY JUDICIAL SYSTEM}

Minor offences in the military are dealt with by 'summary justice', which essentially involves a hearing chaired by a commanding officer. The hearing is not a trial, lawyers are not permitted to be present, and the maximum sentence that can be handed down is 60 days' detention. The potential for injustice in these circumstances is balanced against the military requirement for prompt action to maintain service discipline. Commanding officers are best placed to balance these competing requirements. Officers are rarely dealt with summarily.

Some offences remain sufficiently serious that only the more formal structure of the court martial can properly deal with them. There are three types of court martial: the district courts martial deal with private soldiers and have limited powers of sentence; the general courts martial are convened to deal with officers and private soldiers charged with serious offences, and have no sentencing limitations imposed upon them; the field general courts martial convene only during wartime and can, if necessary, dispense with unnecessary technicalities and deal with an offender swiftly and in proximity to the lines. The selection of officers to sit on courts martial is, for obvious reasons, made from outside the accused's immediate chain of command, and a judge is selected by the Judge Advocate General. The Judge Advocate General is answerable to the Queen by way of the Lord Chancellor and is therefore independent of the Armed Forces.

That is not to say, however, that the court-martial system has been without criticism. At the European Court of Human Rights in Morris v. United Kingdom (2002), it was found that the general structure of the UK court-martial system violated Article 6(1) of the Human Rights Act, giving everyone entitlement to a fair hearing by an independent and impartial tribunal. As a result, in March 2002 all courts martial were temporarily suspended in the UK. Anyone imprisoned following a court martial between October 2000 (when the Human Rights Act was introduced) and March 2002 may be eligible for compensation (Syal, 2002).

\section{MILITARY OFFENCES}

There are a number of specific military offences, including impersonating an officer, absence without leave, and malingering (see, for example, the Army Act 1955, s. 42(1)). In the UK, these come before courts martial very rarely, but in the USA, for example, between September 1986 and March 1995 there were 92 convictions of US Army personnel for either impersonating an officer or wearing unauthorised insignia (Lande, 1997). Leaving aside absence without leave, under Section 10 of the Crown Proceedings Act 1947 the Armed Forces and members thereof could not be prosecuted for negligence in relation to their employees. Malingering could thereforeat least theoretically - be handled quite robustly. Since Section 10 was repealed in the 1987 Act, the situation is more like that of the civilian health services, in which an individual who claims to be ill is generally treated as such.

Occasionally, however, malingering may require more-concerted action such as an administrative discharge from the Armed Forces or (very occasionally) a court martial. Prosecuting individuals for behaviour that might sometimes be seriously self-injurious raises diagnostic and ethical issues. These matters have received considerable attention in US military case law over the past few years and there have been a number of legal decisions that carry the implication that attempted suicide is a crime (Ritchie, 1997).

\section{SENTENCING AND CORRECTION}

A range of sentences are available to the courts martial. Ignoring the death penalty for a moment, the most serious offences are dealt with by transfer to civilian prison accompanied by 'dismissal with disgrace'. There is then a hierarchy of punishments for offences of gradually decreasing seriousness, including detention in the Military Corrective Training Centre in Colchester Garrison, with, and then without, dismissal; reduction in rank; reprimands; and fines. Service personnel who are given a custodial sentence by a civilian court are automatically dismissed.

Certain crimes can still theoretically attract the death penalty under military law. In the Army and Air Force only a general or field general court martial can pass a sentence of death, for assisting the enemy or for mutiny (Army Act 1955 and Air Force Act 1955, ss 24, 25, 26, 31(1) and 32 ). In the Navy the situation is again different: according to the Naval Discipline Act 1957, Sections 2, 3, 4 and 9, offences punishable by death must involve intent to assist the enemy. During the First World War, 351 British soldiers were executed for cowardice or desertion, mostly after field general courts martial (Putkowski \& Sykes, 1993). The last death penalty to be imposed by a court martial was during the Second World War.

\section{COMPULSORY DETENTION}

Military personnel with a major mental illness and who are a danger to themselves 
and occasionally to others cannot be detained under the Mental Health Act 1983 in service hospitals. In the case of personnel serving overseas the situation is more complicated, and compulsory detention is possible only on the authority of an order of the commanding officer under the Armed Forces Act 1981, Section 13, and on the written recommendation of two registered medical practitioners (one in the case of an absolute emergency). There is no uniformed consultant forensic psychiatrist or committed secure health care military facility in the UK, and mentally disordered offenders in the Armed Forces are dealt with through the civilian health care and criminal justice systems.

\section{TEMPER AMENT AND RISK}

Service personnel can be compelled to leave the Armed Forces for a number of reasons: on medical grounds; administratively after admitting to taking illicit substances, or failing a random drug screen (at their commanding officer's discretion); for misconduct; after being given a custodial sentence by a civilian court; or after being found 'temperamentally unsuitable'. An individual who has a history of mental illness that was not disclosed at the time of joining the service can be administratively discharged.

Service personnel recommended for medical discharge are referred to a formal medical board, which makes a final decision independent of the psychiatrist making the recommendation. All medical recommendations made by psychiatrists in the military are informed by detailed occupational and social reports from the individual's commanding officer. Individuals attracting the label of temperamental unsuitability, which in relation to Army personnel is covered by Section 9.4(14) of the Army Act 1955, often have personality difficulties. The decision about whether they are temperamentally unsuited to further service is analogous to the conventional forensic psychiatric dilemma about whether individuals with a personality disorder should go to hospital or prison, and arguably rests as much upon assessment of their character as it does upon that of the origin of their psychological symptoms. As with the hospital/prison dilemma, the

MARK A. TURNER, MRCPsych, LEIGH A. NEAL, MRCPsych, Duchess of Kent's Psychiatric Hospital, Catterick Garrison, North Yorkshire, UK

Correspondence: Dr Mark A. Turner, Duchess of Kent's Psychiatric Hospital, Horne Road, Catterick Garrison, North Yorkshire DL9 4DF, UK. Tel: 01748 873608; fax: 01748 8736I4; e-mail: markturn@dsca.mod.uk

(First received 8 July 2002, final revision 9 September 2002, accepted 8 November 2002)

process of deciding on an appropriate method of discharge reflects the difficulty of deciding between illness and deviance.

Clinical experience indicates that the most common form of temperamental unsuitability is related to borderline personality traits rather than antisocial traits. There is, however, a view that military service attracts individuals with - or encourages the development of - violent tendencies. The more plausible view is that training fosters the discipline and other attributes necessary to control such tendencies. In keeping with this view, in the early 1980s Stuart-Smith found that the incidence of violence among British soldiers was no higher than among civilians of similar age, education and physical fitness (reported by McPherson, 1990). Violence does, however, occur in military settings, and access to weaponry given the dramatically increased chance of a fatality consequent upon its use (Zimring, 1991) - places an extra demand on psychiatric risk assessment. A service psychiatrist can impose occupational restrictions, for example preventing access to live arms or dangerous environments. The notion of risk also has more general connotations in the military. The Armed Forces carry out classified work involving access to weaponry or privileged information. Psychiatrists are sometimes required to give advice on the security classification of such individuals if they demonstrate a change in mental state. Units involved in sensitive work have a very low tolerance of unusual behaviour and illness is detected very early.

\section{CONCLUSIONS}

British military society has its own health care and legal systems, which have simultaneously evolved to balance the traditional military demand of keeping soldiers fit to fight, with the health and judicial requirements of an increasingly liberal Western society. Recently, both systems have come under considerable scrutiny, with the effect that their respective responsibilities are in the process of being transferred from military to civilian control. The inevitable effect of this is to place additional demands on civilian psychiatric services. Minor offending in the military does not usually require the involvement of a psychiatrist and serious crime is rare. There are, however, a number of special circumstances, which require military forensic knowledge.

\section{DECLARATION OF INTEREST}

None.

\section{REFERENCES}

Jones, E., Hodgins-Vermaas, R., Everitt, B., et al (2002) Post-combat syndromes from the Boer War to the Gulf War: a cluster analysis of their nature and attribution. BMJ, 324, 32I.

Lande, R. G. (1997) Special military forensic issues. In Principles and Practice of Military Forensic Psychiatry (eds R. G. Lande \& D. T. Armitage), pp. 199-214. Springfield: Charles C. Thomas.

McPherson, J. (1990) Forensic aspects of the armed forces. In Principles and Practice of Forensic Psychiatry (eds R. Bluglass \& P. Bowden), pp. 13-96. London: Churchill Livingstone.

Putkowski, J. \& Sykes, J. (1993) Shot at Dawn. London: Wharncliffe.

Ritchie, E. C. (1997) Malingering and the United States military. In Principles and Practice of Military Forensic Psychiatry (eds R. G. Lande \& D. T. Armitage), pp. 122-133. Springfield: Charles C. Thomas.

Syal, R. (2002) Court martialled soldiers seek $€ 60,000$ payouts. Daily Telegraph, 17 March.

Winyard, G. (200I) Medical Quinquennial Review: The Future of Defence Health Care. London: Ministry of Defence.

Zimring, F. E. (1991) Firearms, violence and public policy. Scientific American, November, p. 24.

Morris v. United Kingdom [2002] 34 EHRR 52. 